\title{
Microbiological and Hydrochemical Parameters of Deep Wells Used for Drinking Water in Ulaanbaatar, Mongolia
}

\author{
Dulamsuren Ganpurev, Odontuya Gombosuren, Tsiiregzen Andarai, Dariimaa
}

\author{
Battulga, Ichinnorov Amarjargal, Buyanjargal Zolboot, Khureldavaa \\ Otgonbayar, Oyuntsetseg Dolgorjav, Amarsanaa Badgaa*
}

\author{
Laboratory of Ecological Chemistry, Institute of Chemistry and Chemical Technology, Mongolian Academy of \\ Sciences, Ulaanbaatar, Mongolia \\ *Corresponding author.Email: abadgaa@mas.ac.mn
}

\begin{abstract}
Groundwater is not a nutrient-rich environment for microorganisms to grow and thrive, but it is polluted by many environmental factors. These nutrients can exceed the permissible levels in drinking water and can be a reason for spreading highly infectious diseases in the population. Therefore, there is a need to monitor the quality of water from deep wells in ger areas, to study certain correlations, to prevent people from various infectious diseases, to protect the environment, to use water resources properly, and to provide citizens with accurate information on drinking water. Within the framework of the study, samples were taken from 135 deep wells used for drinking and household purposes in the Bayanzurkh, Bayangol, and Sukhbaatar districts of Ulaanbaatar city. The water quality was analyzed for some hydrochemical $\left(\mathrm{NO}_{3}{ }^{-}\right)$and six main microbiological parameters. Due to microbiological parameters, 42 samples (30.6\%) from the surveyed deep wells did not meet the requirements of MNS 0900:2018, the national drinking water standard of Mongolia, and 31 samples (21.9\%) exceeded the nitrate ion content described in above the standard. In the Bayangol district, $88 \%$ of the surveyed sources found that the number of bacterial contaminants in $100 \mathrm{~mL}$ of water exceeded the limit. But in the Sukhbaatar district's summer camp region which is a relatively low populated area was shown a relatively low level of microbiological contamination and nutrient pollution compared to the permissible level in water samples.

According to correlation studies, the nitrate ion concentrations of $12.6 \%$ samples over the permissible value (more than $50 \mathrm{mg} / \mathrm{L}$ ) and high level of bacterial contamination in drinking water, showed a weak correlation.
\end{abstract}

Keywords: Deep wells, Drinking water, Microbiology, Pollution indicators, Pathogens

\section{INTRODUCTION}

Groundwater is the main important source of drinking water. In recent years, excessive water usage in mining affects microbial and chemicals that have adversely polluted groundwater quality $[1,2]$. The contamination of water by microorganisms, mineral fertilizers, and heavy metals occurs mainly in densely populated areas [3]. Depending on the source, groundwater may contain a wide variety of harmless heterotrophic microorganisms such as Flavobacterium spp., Pseudomonas spp., Acinetobacter spp., Moraxella spp., Chromobacterium, Achromobacter spp., and Alcaligenes spp., as well as numerous unidentified bacteria [4-6]. 
To study the microbiological quality of drinking water, the non-pathogenic bacteria originated from human and animal feces counted in water samples [4, 7, 8]. For this purpose, E. coli, Enterococcus spp., and the same sort of bacteria are being used commonly as an indicator on the microbiological study. In our country, E. coli, Enterococcus spp. are also used as a hygienic indication in the microbiological analysis according to the National Standard of Drinking Water (MNS 0900:2018) [9].

Climatic conditions and environmental pollution are external factors that affect physicochemical parameters such as $\mathrm{pH}$, total dissolved solids (TDS), and electrical conductivity (EC). These parameters have a major influence on the biochemical reactions that take place in water. The internal factors include events between bacterial and plankton populations in the water [10]. In addition, the list of drinking water contaminants includes ammonium, nitrite, nitrate, phosphate, and pesticides. Nitrate is one of the most polluting substances in groundwater. Groundwater nitrate pollution can be attributed to livestock, sewage systems, agricultural fertilizers, as well as non-anthropogenic or natural sources of nitrogen [9]. The high level of nitrate in drinking water can cause methemoglobinemia or "blue baby" disease. Therefore, nitrate ion content should be monitored regularly for drinking water quality studies $[11,12]$.

The area of Ulaanbaatar is 4.7 thousand ha or 0.3 percent of the total territory of Mongolia, and 46 percent of our population lives and works here. Due to this overcrowding, ger districts and businesses which are using their own deep well water for use of irrigation and drinking water, risk of depletion and pollution of groundwater resources increasing. Therefore, the main objectives of this research were to determine the microbiological and physicochemical quality of drinking water from deep wells in the Bayanzurkh, Sukhbaatar, and Bayangol districts of Ulaanbaatar and to assess the quality of drinking water.

\section{EXPERIMENTAL}

\subsection{Study Area}

The study covered drinking water wells in three central districts of Bayanzurkh, Sukhbaatar, and Bayangol in Ulaanbaatar city Figure 1. Bayanzurkh district has 28 administrative khoroos (subdistrict), a total area of 126.97 thousand hectares, 104.8 thousand households and 361.7 thousand populations. Sukhbaatar district has 20 khoroos, an area of 21.8 thousand hectares, 36.1 thousand households, and 136.8 thousand populations. Bayangol district has an area of 21.8 thousand hectares, 25 administrative khoroos and a population of 225.8 with 59.5 thousand households.

\subsection{Sample Collection}

A total of 135 well water samples were collected, 55 samples of Bayanzurkh district, 62 samples of Sukhbaatar district, and 18 samples of Bayangol district Figure 1. All well water samples were collected from the source in $1 \mathrm{~L}$ plastic bottles. Determination of water quality including physicochemical and bacteriological parameters was conducted in the laboratory of Ecological chemistry, Institute of Chemistry and Chemical Technology, Mongolian Academy of Sciences. The bacterial analysis was carried within $6 \mathrm{~h}$ of collection.

\subsection{Physico-Chemical Analysis}

Characteristics of physico-chemistry analysis such as $\mathrm{pH}, \mathrm{EC}$, TDS were examined with the HM30P, CM-31P, RM-30P meter (TOA, Japan). Also, nitrate concentrations in water were examined with an S2100UV spectrophotometer [13].

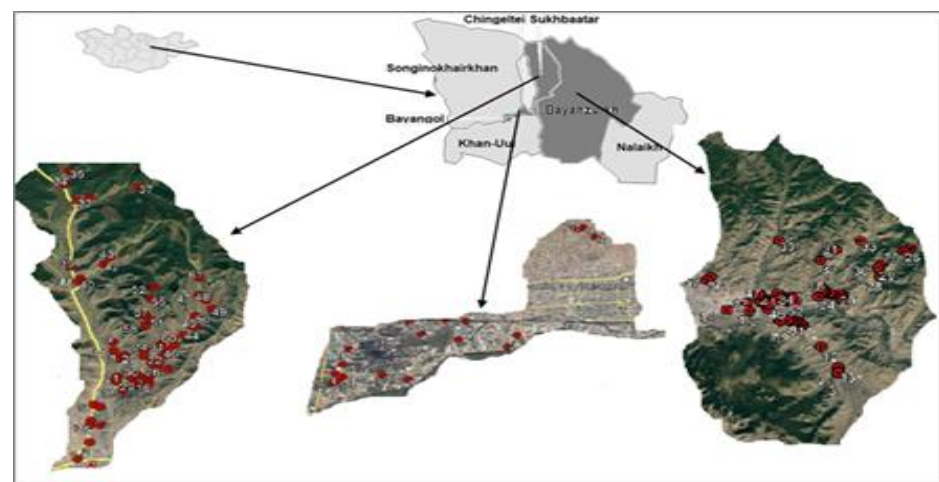

Figure 1. Location of study areas and groundwater sampling points in Ulaanbaatar city 
Table 1. The incubation conditions and microbiological media that are used in microbiological analysis

\begin{tabular}{|c|c|c|c|c|}
\hline Analysis & Methods & $\begin{array}{l}\text { Culture } \\
\text { medium } \\
\text { information }\end{array}$ & $\begin{array}{l}\text { Incubation } \\
\text { conditions } \\
\text { (Temperatur } \\
\text { e, } \\
\text { Hours) }\end{array}$ & Interpretation \\
\hline $\begin{array}{l}\text { Total } \\
\text { Plate } \\
\text { count } \\
(\mathrm{TPC}) \\
\end{array}$ & {$[14]$} & $\begin{array}{l}\text { Plate count agar } \\
\text { (Biolab No: } \\
\text { 09042095) }\end{array}$ & $35-37^{\circ} \mathrm{C} ; 48 \mathrm{~h}$ & $\begin{array}{l}\text { Total Plate Count (TPC) is a method of estimating the } \\
\text { total number of microorganisms (mold, yeast, bacteria) in } \\
\text { a material. }\end{array}$ \\
\hline $\begin{array}{l}\text { Total } \\
\text { Coliforms } \\
\text { (TC) }\end{array}$ & \multirow{3}{*}{ [15] } & \multirow{3}{*}{$\begin{array}{l}\text { ENDO Agar } \\
\text { (Biolab } \\
\text { No:10022078) }\end{array}$} & $35-37^{\circ} \mathrm{C} ; 24 \mathrm{~h}$ & $\begin{array}{l}\text { Bacteria develop sharply } \\
\text { contoured, dark red, mucoid or nucleated colonies. }\end{array}$ \\
\hline $\begin{array}{l}\text { Thermotol } \\
\text { erant } \\
\text { Coliforms } \\
\text { (TTC) }\end{array}$ & & & $44.5^{\circ} \mathrm{C} ; 24 \mathrm{~h}$ & Bacteria develop sharply contoured, dark red colonies. \\
\hline E. coli & & & $37^{\circ} \mathrm{C} ; 24 \mathrm{~h}$ & $\begin{array}{l}\text { Bacteria have a greenish metallic sheen, finally IMV iC } \\
\text { test and }\end{array}$ \\
\hline $\begin{array}{l}\text { Salmonella } \\
\text { spp. }\end{array}$ & [16] & \multirow{2}{*}{$\begin{array}{l}\text { SS agar } \\
\text { (Biolab } \\
\text { No:100120096) }\end{array}$} & $37^{\circ} \mathrm{C} ; 18-48 \mathrm{~h}$ & $\begin{array}{l}\text { Pepton water, buffered broth (enrichment) to plate (streak } \\
\text { with an inoculating loop) the bacterial colonies will } \\
\text { appear colorless with black centers. Will not ferment } \\
\text { lactose, but produce hydrogen sulfide }\left(\mathrm{H}_{2} \mathrm{~S}\right) \text { gas. }\end{array}$ \\
\hline $\begin{array}{l}\text { Shigella } \\
\text { spp. }\end{array}$ & [17] & & $37^{\circ} \mathrm{C} ; 18-48 \mathrm{~h}$ & $\begin{array}{l}\text { Pepton water, buffered broth (enrichment) to plate (streak } \\
\text { with an inoculating loop) the bacterial colonies will be } \\
\text { colorless. } \\
\text { Because Shigella do not ferment lactose or produce } \\
\text { hydrogen sulfide gas. }\end{array}$ \\
\hline
\end{tabular}

\section{RESULTS AND DISCUSSION}

\subsection{Microbiological Analysis}

All samples were examined using the Membrane Filter (MF) technique (Nalgene, 3 branches versatility). The ENDO Agar (EA) medium was used to evaluate the total coliform count in $100 \mathrm{~mL}$ of water sample and thermotolerant coliform count in $100 \mathrm{~mL}$ of water samples. The SS agar was used for cultivating Salmonella spp., Shigella spp. contamination $25 \mathrm{~mL}$ of water. And the total bacterial count in $1 \mathrm{~mL}$ of water sample was analyzed using Plate Count Agar (PCA). All of the studies were conducted according to MNS standards [14-18] and the detailed information is given in Table 1.

Table 2. The results of microbiological analysis of groundwater supplied from total average and comparison with WHO Drinking Water Directive and MNS Drinking Water Directive (n:135)

\begin{tabular}{|c|c|c|c|c|c|c|}
\hline \multirow[b]{2}{*}{ Parameter } & \multirow[b]{2}{*}{ WHO DWG* } & \multirow[b]{2}{*}{$\begin{array}{l}\text { MNS } \\
\text { DWG** }\end{array}$} & \multicolumn{4}{|l|}{ Positive samples } \\
\hline & & & $\begin{array}{l}\text { (Total) } \\
(\%)\end{array}$ & $\begin{array}{l}\text { Bayanzurkh } \\
(\%)\end{array}$ & $\begin{array}{l}\text { Sukhbaatar } \\
(\%)\end{array}$ & $\begin{array}{l}\text { Bayangol } \\
(\%)\end{array}$ \\
\hline $\begin{array}{l}\text { Total plate } \\
\text { count }\left(37^{\circ} \mathrm{C}\right)\end{array}$ & Not mentioned & $100 / \mathrm{mL}$ & $\begin{array}{l}25 * * *(100-732) \\
(18.6)\end{array}$ & $\begin{array}{l}7 \\
(5.2)\end{array}$ & $\begin{array}{l}14 \\
(10.4)\end{array}$ & $\begin{array}{l}4 \\
(3.0)\end{array}$ \\
\hline $\begin{array}{l}\text { Total } \\
\text { Coliforms }\end{array}$ & 0 in $100 \mathrm{~mL}$ & 0 in $100 \mathrm{~mL}$ & $\begin{array}{l}27 \\
(20.0)\end{array}$ & $\begin{array}{l}4 \\
(3.0)\end{array}$ & $\begin{array}{l}8 \\
(5.9)\end{array}$ & $\begin{array}{l}15 \\
(11.1)\end{array}$ \\
\hline $\begin{array}{l}\text { Thermo- } \\
\text { tolerant } \\
\text { Coliforms }\end{array}$ & 0 in $100 \mathrm{~mL}$ & 0 in $100 \mathrm{~mL}$ & $\begin{array}{l}1 \\
(0.7)\end{array}$ & $\begin{array}{l}1 \\
(0.7)\end{array}$ & 0 & 0 \\
\hline E. coli & 0 in $100 \mathrm{~mL}$ & 0 in $100 \mathrm{~mL}$ & $\begin{array}{l}1 \\
(0.7)\end{array}$ & $\begin{array}{l}1 \\
(0.7)\end{array}$ & 0 & 0 \\
\hline $\begin{array}{l}\text { Salmonella } \\
\text { spp. }\end{array}$ & Not mentioned & 0 in $25 \mathrm{~mL}$ & 0 & 0 & 0 & 0 \\
\hline Shigella spp. & Not mentioned & 0 in $25 \mathrm{~mL}$ & 0 & 0 & 0 & 0 \\
\hline
\end{tabular}

* World Health Organization-Guidelines for drinking-water quality - 4th ed, 2011; ** Mongolian National Standart Drinking Water Guidelines 2018; ***Samples higher than permitted level (cfu/mL) 


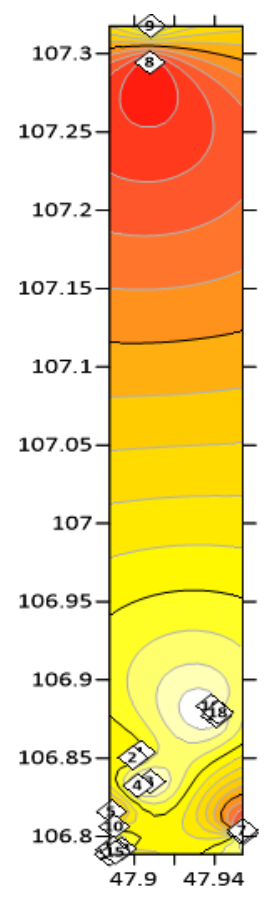

a)

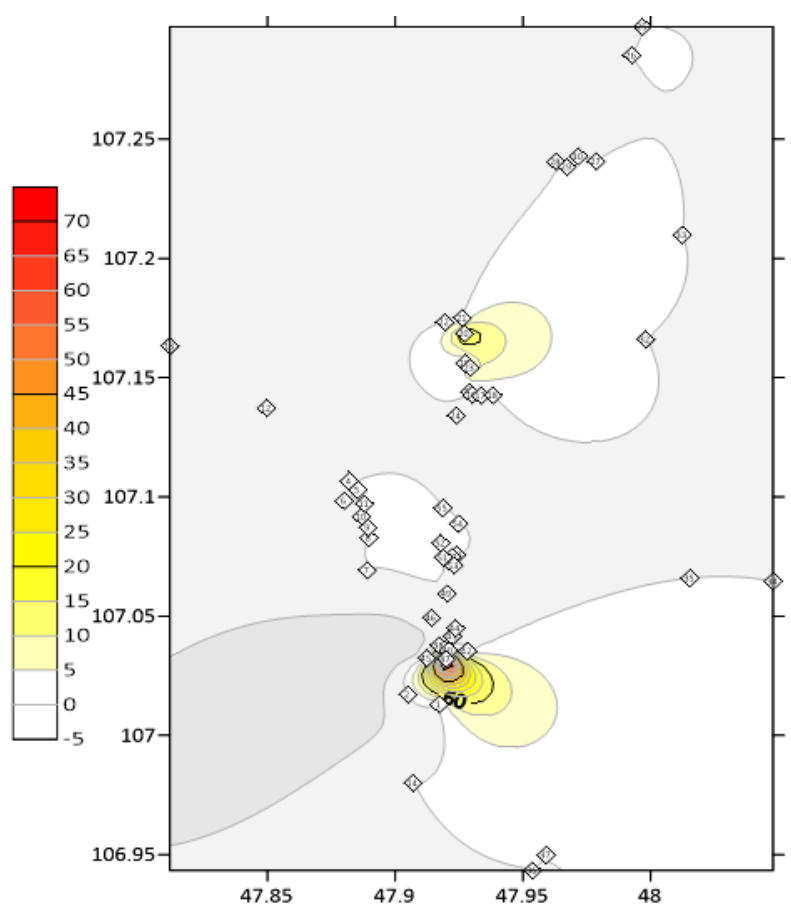

b)

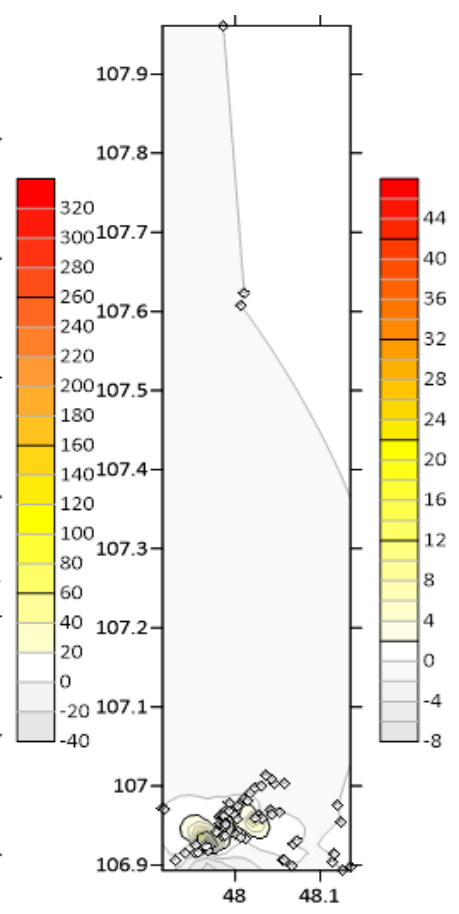

c)

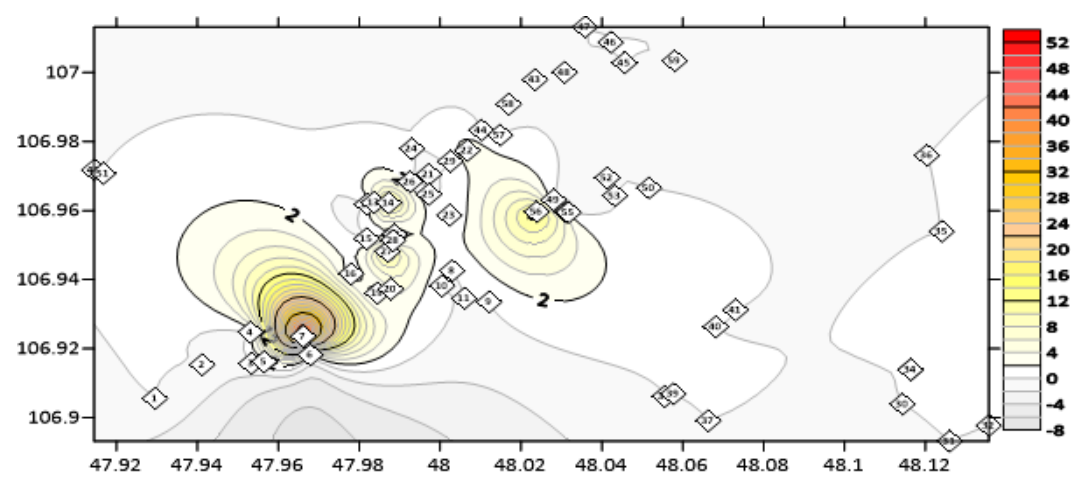

d)

Figure 2. Total Coliform count (cfu/mL) in some district of Ulaanbaatar city. a) Bayangol district b) Bayanzurkh district c) Sukhbaatar district d) Sukhbaatar district's magnification

In addition, coliforms were revealed in a total 27 samples, 4 deep wells in Bayanzurkh district, 8 deep wells in Sukhbaatar district, and 15 deep wells in Bayangol district. Thermotolerant coliform E. coli was detected in only one sample of Bayanzurkh district, Salmonella ssp. and Shigella spp. were not detected in all samples. The study covered 135 deep well water samples from 3 districts, microbiological parameters of 42 deep wells (some well's samples were unsuitable to WHO recommendation and MNS 0900: 2018 in terms of biochemical parameters of TCA and TC) did no meet the requirements of the recommended drinking water (WHO) and the MNS 0900: 2018 standard.
The reason for Total Plate Count (TPC) pollution is likely to be overpopulation and surface water pollution. The most basic test for bacterial contamination of a water supply is the test for total coliform bacteria. Total coliform (TC) counts give a general indication of the sanitary condition of a water supply. The TC, thermotolerant coliforms (TTC), E. coli, and Enterococcus spp. which were found in soil and water could be influenced by surface water contamination by human or animal waste. Freshly deposited feces contains $10^{2}-10^{4}$ times more TTC per gram than Enterococcus spp. Disease-causing microorganisms (pathogens) in these wastes can cause diarrhea, convulsions, nausea, headaches, or 
other symptoms. These pathogens pose a particular risk to the health of infants and children and people with weakened immune systems. Coliform bacteria are important indicators that reveal the fecal originated pathogenic bacteria contamination in water, and coliforms transmit intestinal infections, dysentery, hepatitis, typhoid, and cholera to humans through water [19]. Contamination of well water with coliform bacteria may depend on sanitation and protection in ger areas. One of the reasons for coliforms occurrence in water sources is that some boreholes are close to pit latrines and the poor sanitation of boreholes can lead to groundwater contamination [20].

Salmonella spp. may be found in water sources such as private wells that have been contaminated with the feces of infected humans or animals. But also, Shigella spp. can enter the water through various ways, including sewage overflows, sewage systems that are not working properly, polluted stormwater runoff, and agricultural runoff. Wells may be more vulnerable to such contamination after flooding, particularly if the wells are shallow, have been dug or bored, or have been submerged by floodwater for a long time [21].

Poor microbiological quality of groundwater sources is dominated by unhygienic activities during operation, and health risks and handling conditions should be taken into account at the household level. On the other hand, consumption of microbiologically contaminated groundwater may cause microbial disease distribution in the population. Therefore, well water for domestic use for drinking should be used after disinfection.

\subsection{Physical-chemical parameters}

The results of physico-chemical analysis of well water in Bayanzurkh, Sukhbaatar, and Bayangol districts of Ulaanbaatar are shown in Table 3. EC and $\mathrm{pH}$ are crucial indicators of water parameters, and 135 deep wells in the three districts surveyed have a $\mathrm{pH}$ of $6.54-8.36$ or a weakly alkaline environment, and in terms of $\mathrm{pH}$, they meet the requirements of MNS 0900:2018 and WHO recommendations. Physical parameters such as $\mathrm{pH}, \mathrm{EC}$, and TDS have a major effect on bacterial growth, while $\mathrm{pH}$ values between 3-10.5 increase the growth of indicator or pathogenic microorganisms [11]. The $\mathrm{pH}$ of natural water varies between 5.5-9.0 [22]. The $\mathrm{pH}$ of drinking water does not directly affect human health, but it does have an indirect effect by altering other parameters of water quality, such as the solubility of metals and the viability of pathogenic microorganisms [23]. TDS is a measure of the total content of inorganic substances in water, such as salts and minerals [24]. The content of TDS in groundwater is highly dependent on plant decay, evaporation, wastewater drainage, and the chemical weathering of rocks [25].

The studied well water EC content was ranged from 16.2 to $145.2 \mathrm{mS} / \mathrm{m}$. Out of them, four wells' water did not match MNS 0900:2018 requirements, and these are one well in Bayanzurkh, two wells in Sukhbaatar and one well in Bayangol district. EC measures the electrical conductivity of water, which is directly related to TDS. It exponent, as the concentration of TDS increases, the current flow becomes stronger and the EC content increases accordingly [25].

Table 3. The results of physico-chemical analysis of groundwater supplied from total average and comparison with WHO Drinking Water Directive and MNS Drinking Water Directive (n:135)

\begin{tabular}{|c|c|c|c|c|c|c|c|c|}
\hline \multirow{2}{*}{ Parameter } & \multirow{2}{*}{$\begin{array}{l}\text { WHO } \\
\text { DWG* }\end{array}$} & \multirow{2}{*}{$\begin{array}{l}\text { MNS } \\
\text { DWG** }\end{array}$} & \multirow{2}{*}{$\min$} & \multirow{2}{*}{$\max$} & \multirow{2}{*}{$\begin{array}{l}\text { Samples } \\
\text { higher } \\
\text { than } \\
\text { permitted } \\
\text { level } \\
\text { (Total) }\end{array}$} & \multicolumn{3}{|c|}{ Samples higher than permitted level of Area } \\
\hline & & & & & & $\begin{array}{l}\text { Bayanzurkh } \\
(\%)\end{array}$ & $\begin{array}{l}\text { Sukhbaatar } \\
(\%)\end{array}$ & $\begin{array}{l}\text { Bayangol } \\
(\%)\end{array}$ \\
\hline pH & $6.5-8.5$ & $6.5-8.5$ & 6.54 & 8.36 & 0 & 0 & 0 & 0 \\
\hline $\mathrm{EC}, \mathrm{mS} / \mathrm{m}$ & $\begin{array}{l}\text { Not } \\
\text { mentioned }\end{array}$ & $100 \mathrm{mS} / \mathrm{m}$ & 16.2 & 145.2 & $\begin{array}{l}4 \\
(2.96)\end{array}$ & $\begin{array}{l}1 \\
(0.74)\end{array}$ & $\begin{array}{l}2 \\
(1.48)\end{array}$ & $\begin{array}{l}1 \\
(0.74)\end{array}$ \\
\hline TDS, ppm & $\begin{array}{l}\text { Not } \\
\text { mentioned }\end{array}$ & $\begin{array}{l}\text { Not } \\
\text { mentioned }\end{array}$ & 39 & 680 & 0 & 0 & 0 & 0 \\
\hline $\begin{array}{l}\text { Nitrate } \\
\left(\mathrm{NO}_{3}^{-}\right)\end{array}$ & $50 \mathrm{mg} / \mathrm{L}$ & $50 \mathrm{mg} / \mathrm{L}$ & 0 & 143.8 & $\begin{array}{l}22 \\
(16.3)\end{array}$ & $\begin{array}{l}11 \\
(8.15)\end{array}$ & $\begin{array}{l}7 \\
(5.18)\end{array}$ & $\begin{array}{l}4 \\
(2.96)\end{array}$ \\
\hline
\end{tabular}

* World Health Organization-Guidelines for drinking-water quality - 4th ed, 2011;

** Mongolian National Standart Drinking Water Guidelines 2018 
In addition, the nitrate ions $\left(\mathrm{NO}_{3}^{-}\right)$in the deep wells of the three districts have shown a concentration of $0-143.8 \mathrm{mg} / \mathrm{L}$ Table 3. According to the results, 11 of 55 wells in Bayanzurkh, 7 in 62 wells in Sukhbaatar district, 4 in 18 wells in Bayangol district, or a total of 22 wells, do not match the requirements of MNS0900:2018 and WHO recommendations. Nitrate pollution is one of the challenging aspects of groundwater and is caused by livestock, organic matter, compost decomposition, and wastewater. When high concentrations of nitrogen-containing wastes are released into the environment, they can be oxidized to nitrates and permeable to groundwater [26].
Excessive nitrate levels in drinking water can cause illness and sometimes death. Nitrate is a toxic compound that can cause shortness of breath, neonatal "blue baby" syndrome, and splenic hemorrhage. The main causes of nitrate contamination of groundwater in agricultural areas are fertilizers and animal manure [12].

Previous studies have shown that microorganisms thrive in water with high nitrate content, which is because the microorganisms use nitrate as a food source. In addition, the nitrate contamination is often accompanied by bacterial and pesticide contamination [27].

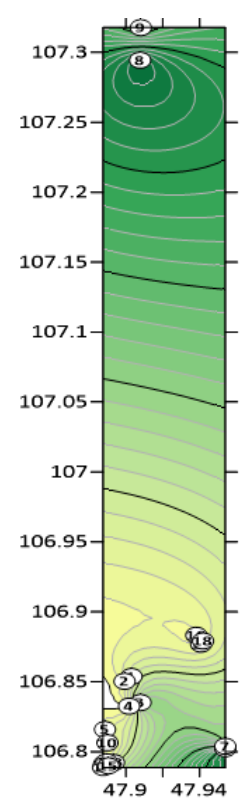

a)

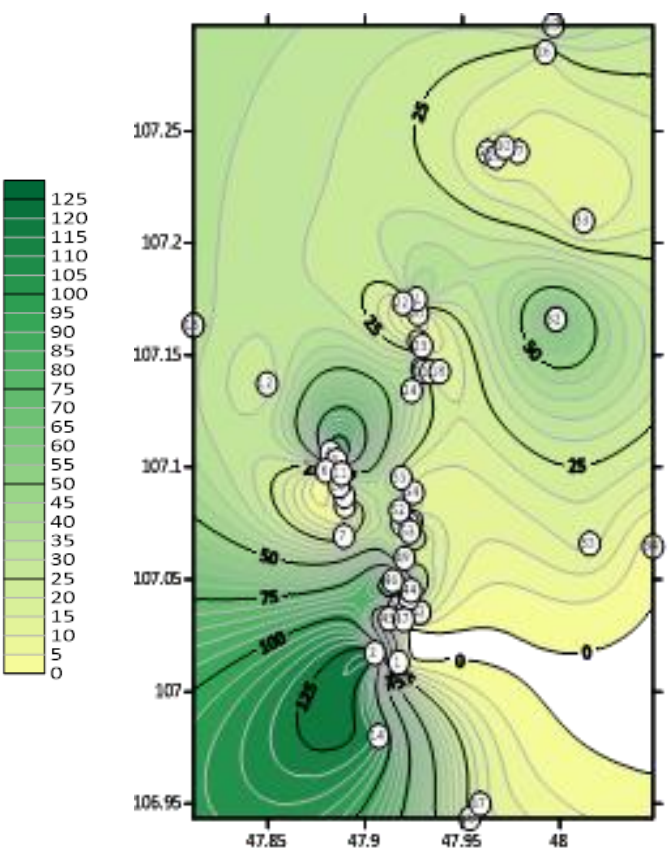

b)

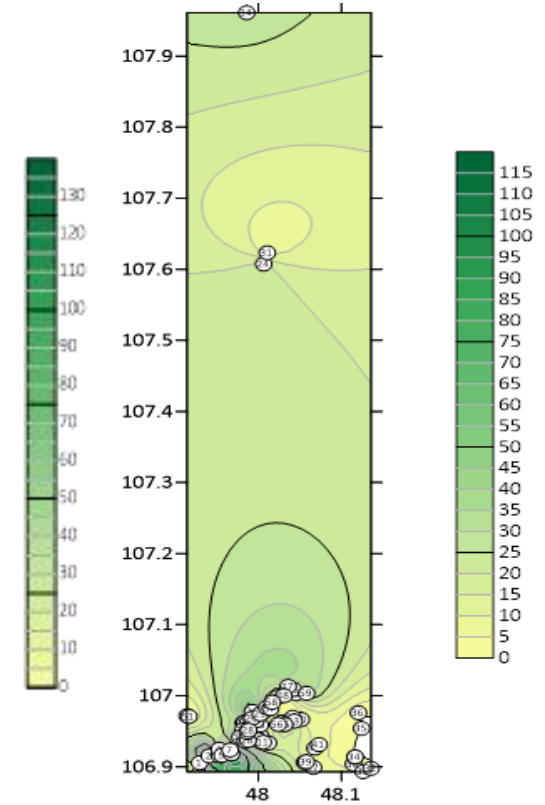

c)

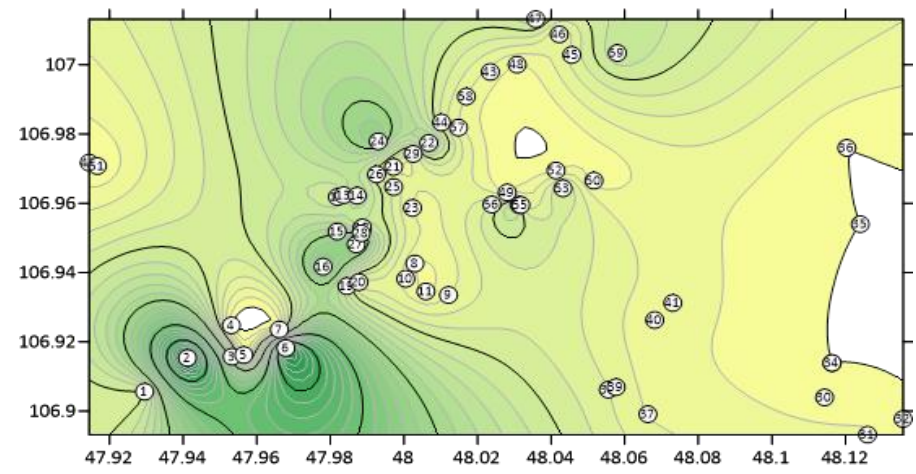

d)

Figure 3. Nitrate ion concentration (mg/L) in some districts of Ulaanbaatar city. a) Bayangol district

b) Bayanzurkh district c) Sukhbaatar district d) Sukhbaatar district's magnification 


\subsection{Correlations}

Table 4 shows the results of calculating the Spearman correlation coefficient between the bacteriological quality, physicochemical parameters, and nitrate ion content of groundwater in Bayanzurkh, Sukhbaatar, and Bayangol districts.

The depth of wells in the Bayanzurkh district was weakly positively correlated with $\mathrm{pH}, \mathrm{EC}$, TDS, $\mathrm{NO}_{3}$, and TPC, negatively correlated with TC. EC was strongly and positively correlated with TDS and $\mathrm{NO}_{3}$, and a very weak positive correlation with TPC and TC. TDS is moderately positively correlated with $\mathrm{NO}_{3}$, while TPC and TC are weakly positively correlated. $\mathrm{NO}_{3}$ was a weakly negatively correlated to TPC and TC. TPC was weakly positively correlated with TC. The $\mathrm{pH}$ is negatively correlated with other parameters. The presence of a negative $\mathrm{pH}$ variable may depend on the season and weather conditions during which the sample is collected.
In the Sukhbaatar district, the depth of the well is weakly positively correlated to $\mathrm{pH}$ and negatively correlated to EC, TC, TDS, $\mathrm{NO}_{3}$, and TPC. The EC showed a strong positive correlation with TDS and $\mathrm{NO}_{3}$, and a very weak positive correlation with TPC and TC. TDS is moderately positively correlated with $\mathrm{NO}_{3}$, while TPC and $\mathrm{TC}, \mathrm{pH}$ are weakly positively correlated. $\mathrm{NO}_{3}$ was weakly positively correlated to TPC and TC. The $\mathrm{pH}$ is negatively correlated with other parameters.

In the Bayangol district, well depth was weakly positively related to $\mathrm{pH}$ and negatively correlated to TC, TDS, $\mathrm{NO}_{3}$ and TPC. The $\mathrm{pH}$ is weakly positively correlated to EC, TDS, $\mathrm{NO}_{3}$, TPC, and TC. EC was strongly positively correlated with TDS and $\mathrm{NO}_{3}$, and showed a very weak positive correlation with TPC and TC. TDS is moderately positively correlated with $\mathrm{NO}_{3}$, while TPC and $\mathrm{TC}, \mathrm{pH}$ are weakly positively correlated. For $\mathrm{NO}_{3}$, it showed a weak positive correlation to TPC and TC.

Table 4. Correlation matrix showing the relationship between bacteriological quality and physico-chemical parameters of groundwater samples in Bayanzurkh, Sukhbaatar, Bayangol district

\begin{tabular}{|c|c|c|c|c|c|c|c|}
\hline \multicolumn{8}{|c|}{ Bayanzurkh } \\
\hline & Depth & pH & EC & TDS & $\mathrm{NO}_{3}$ & TPC & TC \\
\hline Depth & 1.000 & 0.023 & 0.071 & 0.119 & 0.009 & 0.009 & -0.064 \\
\hline pH & & 1.000 & $-0.419^{* *}$ & $-0.752^{* *}$ & $-0.247^{*}$ & -0.111 & -0.019 \\
\hline EC & & & 1.000 & $0.823^{* *}$ & $0.653^{\text {** }}$ & $0.248^{*}$ & 0.124 \\
\hline TDS & & & & 1.000 & $0.582^{* * *}$ & 0.182 & 0.060 \\
\hline $\mathrm{NO}_{3}$ & & & & & 1.000 & -0.040 & -0.204 \\
\hline TPC & & & & & & 1.000 & $0.317^{* * *}$ \\
\hline TC & & & & & & & 1.000 \\
\hline $\mathbf{N}$ & & & & 55 & & & \\
\hline \multicolumn{8}{|c|}{ Sukhbaatar } \\
\hline & Depth & pH & EC & TDS & $\mathrm{NO}_{3}$ & TPC & TC \\
\hline Depth & 1.000 & $0.296^{*}$ & $-0.342^{* * *}$ & $-0.384^{* *}$ & $-0.296^{*}$ & $-0.273^{*}$ & -0.184 \\
\hline pH & & 1.000 & -0.216 & 0.063 & $-0.301^{*}$ & -0.006 & -0.121 \\
\hline EC & & & 1.000 & $0.552^{* *}$ & $0.751^{* *}$ & 0.248 & $0.305^{*}$ \\
\hline TDS & & & & 1.000 & $0.321^{*}$ & $0.266^{*}$ & 0.163 \\
\hline $\mathrm{NO}_{3}$ & & & & & 1.000 & $0.330^{* * *}$ & $0.276^{*}$ \\
\hline TPC & & & & & & 1.000 & $0.371^{\text {*** }}$ \\
\hline TC & & & & & & & 1.000 \\
\hline $\mathbf{N}$ & & & & 62 & & & \\
\hline \multicolumn{8}{|c|}{ Bayangol } \\
\hline & Depth & $\mathrm{pH}$ & $\mathrm{EC}$ & TDS & $\mathrm{NO}_{3}$ & TPC & $\mathrm{TC}$ \\
\hline Depth & 1.000 & 0.251 & -0.007 & 0.007 & -0.321 & 0.046 & -0.175 \\
\hline pH & & 1.000 & 0.289 & 0.300 & 0.079 & $0.405^{*}$ & 0.061 \\
\hline EC & & & 1.000 & $0.998^{* * *}$ & $0.551^{* * *}$ & -0.238 & -0.217 \\
\hline TDS & & & & 1.000 & $0.549^{* *}$ & -0.229 & -0.222 \\
\hline $\mathrm{NO}_{3}$ & & & & & 1.000 & 0.216 & 0.167 \\
\hline TPC & & & & & & 1.000 & $0.664^{* *}$ \\
\hline TC & & & & & & & 1.000 \\
\hline $\mathbf{N}$ & & & & 18 & & & \\
\hline
\end{tabular}




\section{CONCLUSION}

Our study demonstrates that the nitrate ion and microbiological assay results have come together to present a reasonably cohesive image of a positive correlation between nitrate ion concentration and bacteriological contamination of the water.

Further studies are required to determine whether differences in the hydrogeology of the microbial indicators, especially hazardous pathogens like $E$. coli, Salmonella spp., and/or others in drinking water samples may visualize differences in the cohesive background or other environmental factors of the quality indication. Concentrations of TDS, nitrate ion, and microorganisms are increasing in wells in some khoroos of Bayangol district and other densely populated districts compared to a different well group of samples. As a result, residents in these ger areas are at higher risk of consuming water with contaminants that causing sanitation-related diseases, therefore, it is necessary to be disinfected and sterilized. The quality of groundwater for microbiological and physico-chemical contents can be attributed to a variety of sources, including agricultural chemicals, organic waste spills, irrigation water, septic tanks, and sewage infiltration.

In conclusion, urgent precautionary measures are needed to conserve groundwater resources in the rapidly growing region, which is a trouble spot for migration.

\section{ACKNOWLEDGMENTS}

The authors thank the Mongolian Water Services Regulatory Commission, Environmental Department of Ulaanbaatar City, and Mongolian Science and Technology Foundation, and for their financial and other support in carrying out this project. Additional, the authors are grateful to all those who in diverse ways have contributed to the success of this work.

\section{REFERENCES}

[1] Pedley S., Howard G., (1997) The Public Health Implications of Microbiological Contamination of Groundwater. Quarterly Journal of Engineering Geology and Hydrogeology, Vol. 30, 179-188. DOI: 10.1144/GSL.QJEGH.1997.030.P2.10.

[2] Reid D.C., Edwards A.C., Cooper D., Wilson E., Mcgaw B.A., (2003) The Quality of Drinking Water from Private Water Supplies in Aberdeenshire. UK. Water Research, Pergamon.
Vol. 37, 245-254. DOI: 10.1016/S00431354(02)00266-X

[3] Ali Z.N., Abdulkadir F.M., (2012) Physicochemical and Bacteriological Analysis of Well Water in Zango-Awattior KadunaNigeria. Nigerian Journal of Chemical Research, Vol. 17, 17-22.

[4]. Aksu H., Vural A., (2004) Evaluation of Microbiological Risks in Drinking Water. Tesisat, Vol. 98, 120-131.

[5] Roberts T.A., van Schothorst M., Sharpe A.N., BairdParker A.C., Bryan F.L., et al., (1996) The International Commission on Microbiological Specification for Foods (ICMSF). Food Control, Vol. 7, 461-472.

[6] Kölbel-Boelke J., Tienken B., Nehrkorn A., (1988) Microbial Communities in the Saturated Groundwater Environment I: Methods of Isolation and Characterization of Heterotrophic Bacteria. Microbial Ecology, Vol. 16, 17-29. DOI: $10.1007 / \mathrm{BF} 02097402$

[7] Hijnen W., Veendaal D., Speld W.M.H., Visser A., Hoogenboezem W., et al., (2000) Enumeration of Faecal Indicator Bacteria in Large Water Volumes Using on Site Membrane Filtration to Assess Water Treatment Efficiency. Water Research, Vol. 34, 73-85. DOI: 10.1016/S0043-1354(99)00311-5

[8] Rompré A., Servais P., Baudart J., De-Roubin M.-R., Laurent P., (2002) Detection and Enumeration of Coliforms in Drinking Water: Current Methods and Emerging Approaches. Journal of Microbiological Methods, Vol. 49(1), 31-54.

[9] Environment. Health Protection. Safety. Drinking Water. Hygienically Requirements, Assessment of the Quality and Safety., MNS 0900:2018.

[10] Zamxaka M., Pironcheva G., Muyima N.Y.O., (2004) Microbiological and Physico-Chemical Assessment of the Quality of Domestic Water Sources in Selected Rural Communities of the Eastern Cape Province, South Africa. Vol. 30, 333-339. http://www.wrc.org.za.

[11] Mc Casland M., Trautmann N.M., Wagenet R.J., (1985) Nitrate: Health Effects in Drinking Water. Cornell Cooperative Extension, 1-3. 
12] United States Environmental Protection Agency (USEPA). (2004) Drinking Water Regulations. http://www.epa.gov/ safewater/mcl.html.

[13] Bulgan T., (2008) Methods of Water Analysis. Ministry of Environment and Tourism, Ulaanbaatar.

[14] Water Quality- Enumeration of Viable Microorganisms-Count by Inoculation in on a Nutrient Agar Culture Media, MNS ISO 6222:1998.

[15] Water Quality-Detection and Enumiration of Coliform Organisms, Thermotolerant Coliform Organisms and Presumptive E.coli. Part 1. Membrane Filtration Method, MNS ISO 9308$1: 1998$.

[16] Water Quality- Detection of Salmonella Spp. MNS ISO 19250:2017.

[17] Microbiology of Food and Animal Nutrition. Method for Detection of Shigella Spp. . MNS ISO 21567:2011.

[18] Bigras-Poulin M., Ravel A., Bélanger D., Michel P., (2004) Development of Agroenvironmental Indicators to Evaluate the Hygienic Pressure of Livestock Production on Human Health. International Journal of Hygiene and Environmental Health, Vol. 207, 279-295. DOI: $10.1078 / 1438-4639-00290$

[19] World Health Organization. (2011) Guidelines for Drinking-Water Quality. 4th ed.

[20] Palamuleni L., Akoth M., (2015) PhysicoChemical and Microbial Analysis of Selected Borehole Water in Mahikeng, South Africa. International Journal of Environmental Research and Public Health, MDPI AG, Vol. 12, 86208628. DOI: 10.3390/ijerph120808619

[21] Centers for Disease Control and Prevention. (2015) Salmonella and Drinking Water from
Private

Wells.

https://www.cdc.gov/healthywater/drinking/priv ate/wells/disease/salmonella.html.

[22] Hem J.D., (1985) Study and Interpretation of the Chemical Characteristics of Natural Water Third Edition.

[23] Zabed H., Suely A., Faruq G., Sahu J.N., (2014) Water Quality Assessment of an Unusual Ritual Well in Bangladesh and Impact of Mass Bathing on This Quality. Science of the Total Environment, Vol. 472, 363-369. DOI: 10.1016/j.scitotenv.2013.11.051

[24] Olajire A.A., Imeokparia F.E., (2001) Water Quality Assessment of Osun River: Studies on Inorganic Nutrients. Environmental Monitoring and Assessment, Vol. 69, 17-28. DOI:10.1023/A:1010796410829

[25] Dandwate S., (2012) Study of Physicochemical Parameters of Groundwater Quality of Kopargaon Area, Maharastra State, India DuringPre-Monsoon and Post-Monsoon Seasons. Journal of Chemistry, Vol. 9, 15-20. DOI: $10.1155 / 2012 / 650212$

[26] Popoola L., Yusuff A., Aderibigbe T., (2019) Assessment of Natural Groundwater PhysicoChemical Properties in Major Industrial and Residential Locations of Lagos Metropolis. Applied Water Science, Vol. 9, 1-10. DOI: 10.1007/s13201-019-1073-y

[27] Harley S., (2002) Water Quality Matters. Water Quality Testing March. 1-4. http://www5.agr.gc.ca/resources/prod/doc/pfra/p df/water quality testing e.pdf. 